\title{
Taxonomic, phylogenetic and functional diversity of an urban Amazonian avifauna
}

\author{
Alexander C. Lees ${ }^{1,2,3}$ • Nárgila G. Moura ${ }^{2,3}$ \\ Published online: 4 April 2017 \\ (C) The Author(s) 2017. This article is published with open access at Springerlink.com
}

\begin{abstract}
Amazonia is undergoing rapid urbanisation, but nothing has been published on the structure and function of urban Amazonian avifaunas. Here we present the results of a year-long survey of the avifauna of an Amazonian city, exploring temporal variation in its taxonomic, phylogenetic and functional diversity. We found urban bird communities to be taxonomically depauperate and dominated by a small subset of common species typical of second growth and river-edge habitats. Broad patterns of phylogenetic community similarity typically resembled those found in other studies on urban Neotropical bird assemblages, with insectivores the dominant guild. There was significant temporal variation in taxonomic and phylogenetic structure owing to the seasonal arrival and departure of a regionally overrepresented minority of migratory species. Although the urban avian assemblage is of limited regional conservation value, it may still offer significant biodiversity services and represent one of few points of contact for local people with biodiversity.
\end{abstract}

Electronic supplementary material The online version of this article (doi:10.1007/s11252-017-0661-6) contains supplementary material, which is available to authorized users.

Alexander C. Lees

alexander.lees@mmu.ac.uk

1 Division of Biology \& Conservation Ecology, School of Science \& the Environment, Manchester Metropolitan University, Manchester M1 5GD, UK

2 Cornell Lab of Ornithology, Cornell University, Ithaca, NY 14850, USA

3 Coordenação de Zoologia, Museu Paraense Emílio Goeldi, Caixa Postal 399, CEP, Belém, Pará 66040-170, Brazil
Keywords City birds · Brazil · Habitat associations · Non-native species · Migrants · Breeding

\section{Introduction}

Over half of the world's human population now resides in cities covering less than $3 \%$ of the planet's terrestrial surface (United Nations 2014). This urbanisation is increasing most dramatically in the tropics fuelled by high birth rates and ruralurban migration (United Nations 2014). Although the conservation of biodiversity in urban areas is intrinsically important (Niemelä 1999), retaining biodiversity is also crucial to minimally maintain important ecosystem services (Dearborn and Kark 2010). Despite recognition by the Convention on Biological Diversity (United Nations Environment Programme 2007) of the importance of biodiversity in cities, our understanding of the impacts of urbanisation on biodiversity in many regions is lacking (Ortega-Álvarez and MacGregor-Fors 2011).

Amazonia is experiencing rapid urbanisation; between 1970 and 2010, the urban population within the Brazilian Amazon experienced a growth rate of over $500 \%$ and urban residents now represent around $75 \%$ of the total regional population (IBGE - Instituto Brasileiro de Geografia e Estatística 2016). Despite the proliferation of research into the impacts of other forms of land-cover change on Amazonian biodiversity (Peres et al. 2010) and birds in particular (e.g. Moura et al. 2013) our knowledge of how its biota is adapting to urban areas is very limited (OrtegaÁlvarez and MacGregor-Fors 2011). Understanding how Amazonian bird species respond to urban areas ought to give insight into both the resilience and adaptability of different avian lineages (Bonier et al. 2007) and shed light on what ecosystem services might be retained in urban areas. Moreover, there are 
specific provisions for considering the importance of urban biodiversity within the Global Cities Covenant on Climate (Mexico City Pact) and at present Manaus is the only Amazonian municipality signatory (Inoue 2012).

Here we investigate the spatio-temporal structure and function of an urban Amazonian avian assemblage for the first time. We explore variation in taxonomic, phylogenetic and functional diversity through the full annual cycle, identifying migrants and transients and their geographical origins, as well as permanent residents and breeding species. We also identify habitat associations of species within the assemblage based on published classifications to understand the source habitats for colonists of this novel Amazonian habitat.

\section{Methods}

\section{Study area}

The city of Belém is located in Pará state in north-east Brazil (approximately $1^{\circ} \mathrm{S}, 48^{\circ} \mathrm{W}$ ) and is the second largest in the Brazilian Amazon with a population of approximately 1.5 million people at a density of 1351.8 people $/ \mathrm{km}^{2}$ (IBGE - Instituto Brasileiro de Geografia e Estatística 2016). The city lies in the $243,000 \mathrm{~km}^{2}$ Belém Center of Endemism (BCE) which has been subject to the highest proportion of forest loss of any Amazonian interfluvial region and retains less than $24 \%$ of its original primary forest cover (Almeida and Vieira 2010). Founded on 12 January 1616 the city replaced the natural climax vegetation of dense ombrophilous terra firma and várzea (seasonally flooded) forests. The climate is hot and humid with annual precipitation of $2834 \mathrm{~mm}$.

We sampled a $5 \mathrm{~km}$ transect (Fig. S1) in the SW of the city that traversers representative sections of habitats in a district of the city with only $4.3 \%$ vegetative cover (Luz and Rodrigues 2014). The route passes both high and low rent housing areas along the Rua dos Mundurucus, a 5.2 ha urban park (the Praça Batista Campos), a stretch of the Rio Guamá along a recently gentrified promenade (Portal da Amazonia) backed by derelict 'waste ground' and finishes outside the Mangal das Garças park. The first half of the transect includes $1 \mathrm{~km}$ of tree-lined section (mostly Mangifera indica) in a more affluent suburb, whilst the Praça Batista Campos has a more diverse tree community also including Ceiba pentandra, Euterpe oleracea, Minquartia guianensis, Caesalpinia echinata and Platonia insignis. The poorer suburbs have very little tree cover, whilst the abandoned area by the Portal da Amazonia is mostly grassland with some encroaching scrub. The foreshore in front of the promenade is mudflats exposed at high tide and backed by short grassland, with some tall monodominant stands of Montrichardia linifera towards the Mangal das Garças.

\section{Bird sampling}

We sampled birds along this $5 \mathrm{~km}$ transect from August 2014 to July 2015, surveys were undertaken from dawn (between 0535 and 0600) and lasted two hours. This transect was travelled 54 times, between one and eight times per month dependent on meteorological conditions, totalling $270 \mathrm{~km}$. We recorded all species seen and heard along this route, obtaining voucher images of any unusual taxa, which, along with the raw data were deposited online at www.ebird.org. We paid special attention for any signs of breeding behaviour and used the eBird breeding codes (Supporting Information Table S1) to define the likelihood of breeding, scoring evidence as confirmed, probable and possible.

\section{Functional classification of bird species}

Bird species were classified to trophic guild based on (Wilman et al. 2014), we divided the community into the broad categories 'plant/seed eaters', 'insectivores', 'omnivores', 'frugivores/nectarivores', and 'vertebrate/fish/scavenger' feeders. Data on body mass was also extracted from Wilman et al. (2014) or genus level averages where no data was available $(n=2)$. We assigned species native or non-native status based on Novaes and Lima (1998). Migratory status was extracted from the Birdlife Datazone database http://www.birdlife. org/datazone/index.html and Parker et al. (1996). We assigned species to the categories 'resident' for species which remain in the Belém area throughout the year; 'Boreal migrant' for Nearctic-Neotropical migrants breeding in North America and migrating south to the Neotropics; 'Austral migrant/partial austral migrant' for species for which part or all of their population migrate north from breeding areas in southern South America to winter in Amazonia and 'Intratropical migrant' for species which undertake seasonal movements within Amazonia (categories sensu Faaborg et al. 2010 based on classifications from the Birdlife Datazone). We used the Parker et al. (1996) database to look at habitat affinities of the community, where species may have more than one occupied habitat type. We also used the Birdlife Datazone database to classify the threat status of species on the IUCN Global Red List.

\section{Data analysis}

We extracted phylogenetic trees from a global avian phylogeny (Jetz et al. 2012) based on the Hackett backbone (Hackett et al. 2008) using 500 phylogenies. The resulting phylogram was visualized and edited using the FigTree $\mathrm{v}$ 1.4.1 software (http://tree.bio.ed.ac.uk/software/figtree/). We calculated six measures of phylogenetic diversity monthly: phylogenetic diversity (PD), sesPD (the standard effect size (SES) of PD), MPD (mean pairwise 
distance), sesSMPD (adjusted for species richness, MNTD (mean nearest taxon distance), sesMNTD (MNTD adjusted for species richness). We performed these metrics using the 'picante' (Kembel et al. 2010). To check if there was difference among months we performed the ANOVA function and type III sums of squares in the 'car' package in $\mathrm{R}$ version 3.2.3 (R Core Development Team 2014).

\section{Results}

\section{Community structure and traits}

We recorded 99 bird species during our survey (Fig. 1), of which five were non-native: Feral Pigeon (Columba livia var. domestica), Jandaya Parakeet (Aratinga jandaya), Common Waxbill (Estrilda astrild), House Sparrow (Passer domesticus) and Campo Troupial (Icterus jamacaii). Although representing only $5.1 \%$ of the total species richness, exotics accounted for $19.0 \%$ of total bird abundance and included $100 \%$ of the regional species pool of exotic species (Table 1). Species abundance and biomass was heavily skewed to a few numerically dominant species (Table 1, Fig. 1a, Supporting Information Table S2). The most frequently recorded of which was Black Vulture (Coragyps atratus) with 1732 individuals counted. There were more records of the most abundant eight species combined than all remaining 91 species; fewer than five individuals were recorded of 28 of these species.

Breeding evidence was 'confirmed' for 31 species, 'probable' for 20 species and 'possible' for 13, there was no evidence for breeding activity for the remaining 35 species (Supporting Information Table S3). Most of the species recorded were resident (66), of the remainder, nine were Boreal migrants from North America, 12 were austral/partial austral migrants and 12 intratropical migrants (Fig. 2b).
However migrant species were over-represented in the totals in comparison with the total regional species pool (Table 1). Among the guilds, insectivores dominated the community with 53 species ( $53.3 \%$ of the total), although this included a long-tail of rarely-recorded species, a distribution not reflected in the remaining guilds. Omnivores (17 species) were the next commonest guild followed by vertebrate/fish/scavenger feeders (16), fruit/nectar feeders (10) and plant/seed eaters (7). However, as a function of the regional species pool, insectivores were in fact under-represented in comparison to omnivores, which were represented by proportionately more species Table 1). The guild of vertebrate, scavenger and piscivorous feeders dominated by weight, accounting for $40.4 \%$ of total avian biomass. All species were globally 'Least Concern' with the exception of the Near-Threatened Semipalmated Sandpiper (Calidris pusilla).

\section{Spatio-temporal structure}

The taxonomic diversity of birds in our study region varied throughout the annual cycle, driven by the arrival and departure of different cohorts of migrating birds. Species richness was highest in January-April when Boreal migrants were present alongside intratropical migrants. Taxonomic diversity subsequently decreased with the departure of these species, a change which was not offset by the arrival of smaller numbers of Austral migrants and partial Austral migrants. This difference in taxonomic diversity over the annual cycle was mirrored and accentuated in terms of phylogenetic diversity given the higher phylogenetic diversity of many of the migrant taxa resulting in higher values of mean pairwise differences (Fig. 2, $\mathrm{S} 2, \mathrm{~S} 3$ ). The temporal trend in mean pairwise distance also mirrored the pattern of PD with significant differences between the Boreal 'summer' and 'winter periods. This loss of large phylogenetically divergent waterbirds distributed across a wide range of clades, was not temporary compensated for by
Fig. 1 Relative abundance (a) and phylogenetic structure (b) of an urban Amazonian bird community

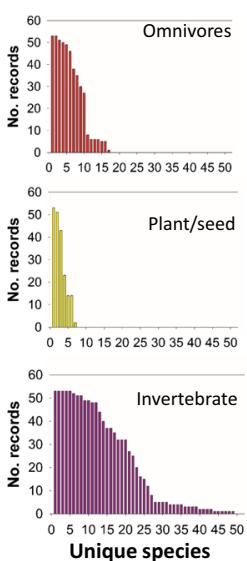

a)
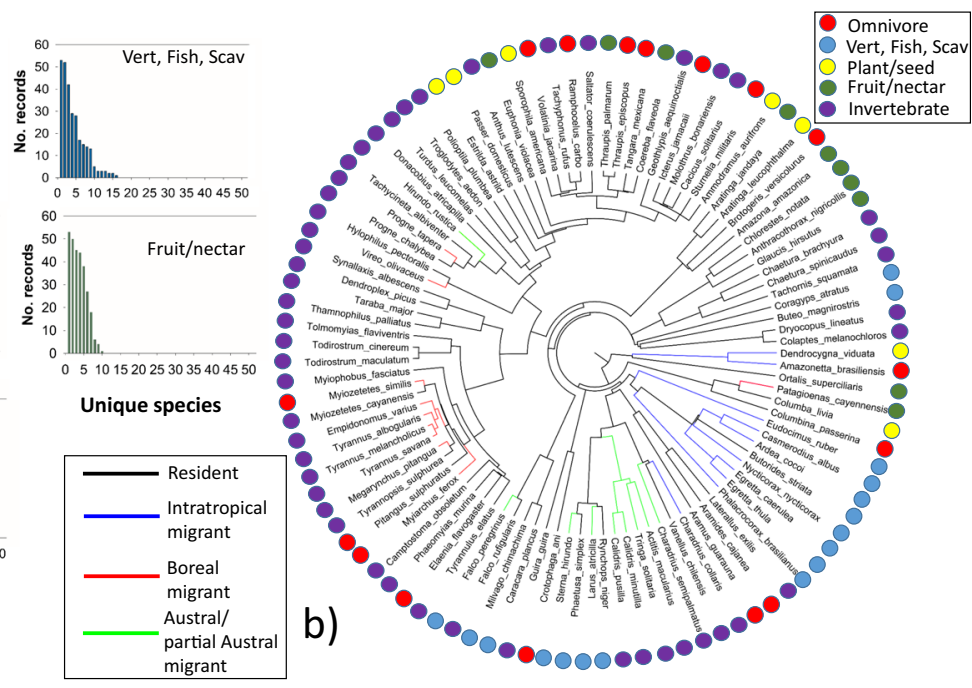
Table 1 Species richness, total abundance and total biomass of species with different migratory statuses and different diet guilds. The total number of species in the regional species pool, extracted from Novaes and Lima (1998) and percentage of the total is given in parentheses

\begin{tabular}{llll}
\hline & No. species & Total \# individuals & Estimated total biomass $(\mathrm{kg})$ \\
\hline Migratory status & & & \\
Resident native & $61(437,13 \%)$ & 9210 & 197.85 \\
Resident introduced & $5(5,100 \%)$ & 3212 & 20.89 \\
Austral migrant & $12(17,71 \%)$ & 757 & 12.34 \\
Boreal migrant & $9(29,31 \%)$ & 1215 & 12.33 \\
Intratropical migrant & $12(35,34 \%)$ & 2537 & 93.94 \\
Diet Guild & & & \\
Omnivore & $17(60,28.3 \%)$ & 3497 & 47.02 \\
Vert fish scav & $16(63,25.4 \%)$ & 4510 & 93.94 \\
Plant/seed & $7(40,17.5 \%)$ & 3163 & 29.36 \\
Fruit/nectar & $10(97,10.3 \%)$ & 923 & 17.42 \\
Insectivore & $53(263,20.1 \%)$ & 4838 & 44.21 \\
\hline
\end{tabular}

the gain in Austral and partial migrants which were phylogenetically clustered. These changes resulted in changes in trophic structure through the annual cycle (Fig. 3) as fewer piscivores and more insectivores were present during the austral winter. We did not however find significant differences in the mean nearest taxon distance throughout the annual cycle (Fig. S2, S3) suggesting that despite migration there is still relative phylogenetic evenness.
Fig. 2 Species richness (a), Phylogenetic diversity (PD: b) and mean pairwise difference (MPD: c) of bird communities throughout the annual cycle. Nonsignificant pairwise differences between months are indicated by the presence of the same letter
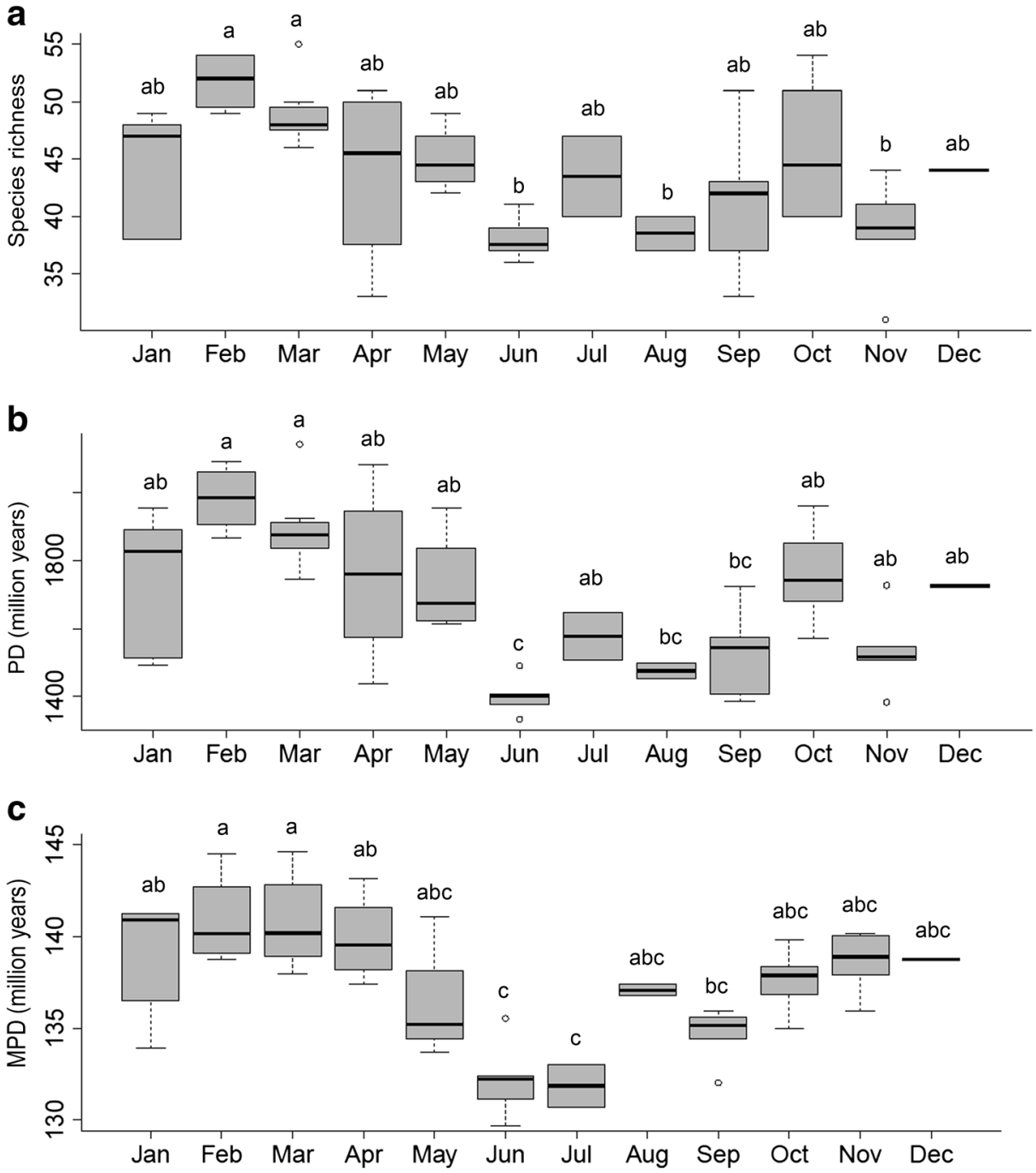


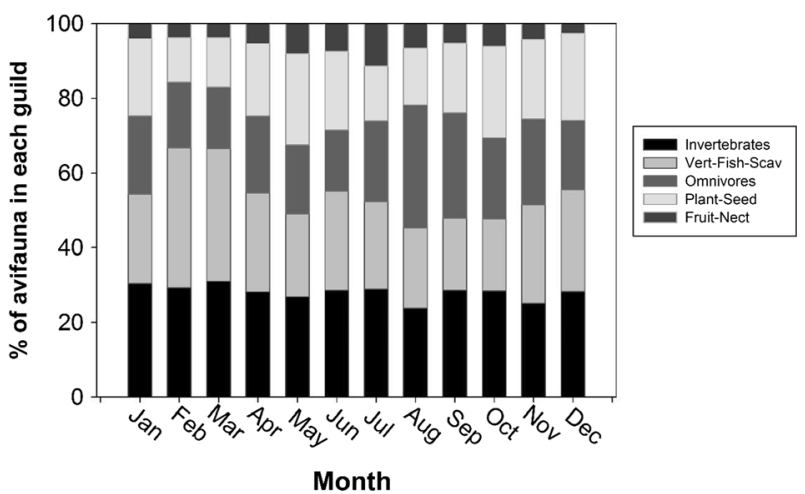

Fig. 3 Variation over the annual cycle of the percentage of individuals within five different foraging guilds

\section{Habitat affinities}

Comparison of habitat affinities with the Parker et al. classifications show that the community is most similar to that occupying other 'secondary' habitats with $44.4 \%$ of species occurring in secondary forest, $37.3 \%$ in 'second growth scrub' and $19.1 \%$ in pastures/agricultural lands (Table 2). The strongest affiliation for a 'primary habitat' was 'river edge forest' which was occupied by $24 \%$ of species, followed by freshwater marshes $(19.1 \%)$ and 'riparian thickets' $(10.1 \%)$. Only $9.1 \%$ of species were typically found in 'tropical lowland evergreen forest' which is the region's dominant natural climax habitat.

Table 2 Habitat associations of species according to their listing in the Parker et al. database

\begin{tabular}{lll}
\hline Parker et al. habitat category & No. species & $\%$ species \\
\hline Secondary forest & 44 & 44.4 \\
Second-growth scrub & 37 & 37.4 \\
River-edge forest & 24 & 24.2 \\
Pastures/agricultural lands & 19 & 19.2 \\
Freshwater marshes & 19 & 19.2 \\
Riparian thickets & 10 & 10.1 \\
Tropical lowland evergreen forest & 9 & 9.1 \\
Arid lowland scrub & 9 & 9.1 \\
Low, seasonally wet grassland & 9 & 9.1 \\
River island scrub & 9 & 9.1 \\
Flooded tropical evergreen forest & 7 & 7.1 \\
Mangrove forest & 7 & 7.1 \\
Saltwater/brackish & 7 & 7.1 \\
Coastal sand beaches/mudflats & 7 & 7.1 \\
Riverine sand beaches & 2 & 2.0 \\
Palm forest & 1 & 1.0 \\
\hline
\end{tabular}

\section{Discussion}

Our survey is the first ever undertaken of an urban Amazonian avifauna; we found the urban assemblage to be depauperate retaining only 99 species, representing $20.5 \%$ of the regional pool of 482 species (Novaes and Lima 1998) although 14\% of these species are now potentially locally extinct (Moura et al. 2014). Previous studies in Neotropical cities have reported similarly proportionately low totals e.g. 55 species in 5 months at Xalapa, Mexico (Escobar-Ibáñez and MacGregor-Fors 2016), 143 species in 20 months in Porto Alegre, Brazil (Fontana et al. 2011), 66 species in ten months in Uberlândia, Brazil (Torga et al. 2007) and 57 species in 6 months at La Paz, Bolivia (Villegas and Garitano-Zavala 2010).

This Amazonian assemblage in Belém was taxonomically and phylogenetically seasonally dynamic, composed principally of resident species associated with secondary habitats, with a small number of species numerically dominant. These broad patterns mirror those found in other human-dominated Amazonian land-uses (e.g. Moura et al. 2013) which generally retain few forest-associated species. A maximum of 64 species (64.6\%) of the community were suspected of breeding behaviour, with the remainder as migrants or transients. This is still a surprisingly high number considering the ostensibly 'harsh' anthropogenic environment and we did find some nests in surprising locations, such as one of Short-crested Flycatcher (Myiarchus ferox) in a traffic light for example. Insectivores were the dominant trophic guild followed by frugivores, whilst plant/seed eaters were very rare, in contrast with most studies of urban avifaunas (Ortega-Álvarez and MacGregor-Fors 2011).

The dominance of the community by insectivorous birds hint at a potential role for these species in the control of insect pests including disease vectors; a research avenue that has largely been overlooked (Wenny et al. 2011). The potential role of this ecosystem service and that conducted by the numerically dominant Black Vultures in waste removal and disease regulation ought to be subject to future research. The relative rarity of granivores and frugivores is presumably a reflection of the relative rarity of suitable foodplants in urban systems given the high vagility of these groups (Lees and Peres 2009). Identifying and then planting keystone food plants would likely be a relatively easy way of increasing urban avian biodiversity (Stagoll et al. 2010). The pattern of disproportionate abundance of non-native species we observed has also been reported from other urban regions of the Neotropics (e.g. Ortega-Álvarez and MacGregor-Fors 2011). Non-native species only seem to manage to gain a toe-hold in Amazonia in urban systems; our own exhaustive inventories of rural agricultural regions failed to find evidence of colonisation of exotic species (e.g. Mahood et al. 2012; Moura et al. 2013).

Broad patterns of phylogenetic community similarity mirror that observed in other studies on urban Neotropical bird assemblages which were also numerically dominated by 
members of the Tyrannidae (Ortega-Álvarez and MacGregorFors 2011). However, the 18 species recorded in our study still only represent $33.3 \%$ of all the Tyrannidae recorded in the metropolitan region (Novaes and Lima 1998). Other clades within the suboscine passerine group were even more underrepresented; the species of antbirds make up just $8.3 \%$ of the total species richness (24) of that group which is typically numerically dominant in Neotropical forests.

Phylogenetic diversity varied significantly through the annual cycle owing to the impacts of migration, highlighting the importance of temporal sampling in assessing phylogenetic diversity within communities with high numbers of migrants. The dynamism of both taxonomic and phylogenetic diversity within this system is also notable given the pervasive assumption of residency in Neotropical avifaunas (Faaborg et al. 2010) and is a strong argument for sampling across the annual cycle, particularly when communities include migrant waterbirds.

Although, urban avian biodiversity in Belém was impoverished, it should still be valued given the ecosystem services, such as predation on phytophagous and biting insects (Whelan et al. 2015) that the community provides. These improve the urban environment and enhance the wellbeing and quality of life of urban dwellers (Savard et al. 2000). Charismatic members of the urban avifauna, like the nesting Great Egrets (Casmerodius albus) in the Praça Batista Campos may provide one of few connections that many Amazonian urban residents have to the natural world; reinforcing the importance of Amazonian conservation far beyond the city's boundaries.

Open Access This article is distributed under the terms of the Creative Commons Attribution 4.0 International License (http:// creativecommons.org/licenses/by/4.0/), which permits unrestricted use, distribution, and reproduction in any medium, provided you give appropriate credit to the original author(s) and the source, provide a link to the Creative Commons license, and indicate if changes were made.

\section{References}

Almeida SA, Vieira ICG (2010) Centro de Endemismo Belém: status da vegetação remanescente e desafios para a conservação biologica e restauração ecológica. Rev Estud Univ 36:95-111

Bonier F, Martin PR, Wingfield JC (2007) Urban birds have broader environmental tolerance. Biol Lett 3:670-673

Dearborn DC, Kark S (2010) Motivations for conserving urban biodiversity. Conserv Biol 24:432-440

Escobar-Ibáñez JF, MacGregor-Fors I (2016) Peeking into the past to plan the future: assessing bird species richness in a neotropical city. Urban Ecosyst 19:657-667

Faaborg J, Holmes RT, Anders AD, Bildstein KL, Dugger KM, Gauthreaux SA, Heglund P, Hobson KA, Jahn AE, Johnson DH, Latta SC (2010) Recent advances in understanding migration systems of new world land birds. Ecol Monogr 80:3-48

Fontana CS, Burger MI, Magnusson WE (2011) Bird diversity in a subtropical south-American City: effects of noise levels, arborisation and human population density. Urban Ecosyst 14:341-360
Hackett SJ, Kimball RT, Reddy S, Bowie RC, Braun EL, Braun MJ, Chojnowski JL, Cox WA, Han KL, Harshman J, Huddleston CJ (2008) A phylogenomic study of birds reveals their evolutionary history. Science 320:1763-1768

IBGE - Instituto Brasileiro de Geografia e Estatística (2016) Censo demográfico 2010. Available at: http://www.ibge.gov. br/home/estatistica/populacao/censo2010/default.shtm Accessed 28 June 2016

Inoue C (2012) Governance of global climate change in the Brazilian Amazon: the case of Amazonian municipalities of Brazil. Rev Brasil Polít Int 55:170-189

Jetz W, Thomas GH, Joy JB, Hartmann K, Mooers AO (2012) The global diversity of birds in space and time. Nature 491:444-448

Kembel SW, Cowan PD, Helmus MR, Cornwell WK, Morlon H, Ackerly DD, Blomberg SP, Webb CO (2010) Picante: R tools for integrating phylogenies and ecology. Bioinformatics 26:1463-1464

Lees AC, Peres CA (2009) Gap-crossing movements predict species occupancy in Amazonian forest fragments. Oikos 118:280-290

Luz LM, Rodrigues JEC (2014) Análise do índice da cobertura vegetal em áreas urbanas: estudo de caso da cidade de Belém-PA. Bolet Amazôn Geograf 1:43-57

Mahood SP, Lees AC, Peres CA (2012) Amazonian countryside habitats provide limited avian conservation value. Biodivers Conserv 21: 385-405

Moura NG, Lees AC, Aleixo A, Barlow J, Dantas SM, Ferreira J, Lima MDFC, Gardner TA (2014) Two hundred years of local avian extinctions in eastern Amazonia. Conserv Biol 28:1271-1281

Moura NG, Lees AC, Andretti CB, Davis BJ, Solar RR, Aleixo A, Barlow J, Ferreira J, Gardner TA (2013) Avian biodiversity in multiple-use landscapes of the Brazilian Amazon. Biol Conserv 167:339-348

Niemelä J (1999) Ecology and urban planning. Biodivers Conserv 8:119-131

Novaes FC, Lima MFC (1998) Aves da Grande Belém: Municípios de Belém e Ananindeua. Museu Paraense Emílio Goeldi, Belém

Ortega-Álvarez R, MacGregor-Fors I (2011) Dusting-off the file: a review of knowledge on urban ornithology in Latin America. Landsc Urban Plan 101:1-10

Parker T, Stotz D, Fitzpatrick J (1996) Database A: zoogeography and ecological attributes of bird species breeding in the Neotropics. In: Stotz D, Fitzpatrick J, Parker TA III, Moskovits D (eds) Neotropical birds: ecology and conservation. University of Chicago Press, Chicago, pp 131-291

Peres CA, Gardner TA, Barlow J, Zuanon J, Michalski F, Lees AC, Vieira IC, Moreira FM, Feeley KJ (2010) Biodiversity conservation in human-modified Amazonian forest landscapes. Biol Conserv 143: 2314-2327

R Core Development Team (2014) R: a language and environment for statistical computing. R Foundation for Statistical Computing, Vienna

Savard JPL, Clergeau P, Mennechez G (2000) Biodiversity concepts and urban ecosystems. Landsc Urban Plan 48:131-142

Stagoll K, Manning AD, Knight E, Fischer J, Lindenmayer DB (2010) Using bird-habitat relationships to inform urban planning. Landsc Urban Plan 98:13-25

Torga K, Franchin AG, Júnior OM (2007) A avifauna em uma seção da área urbana de Uberlândia, MG. Biotemas 20:7-17

United Nations (2014) World urbanization prospects, the 2014 revision. New York: United Nations Department of Economic and Social Affairs. Available at: http://esa.un.org/unpd/wup/FinalReport/WUP2014Report.pdf Accessed 25 Sept 2016

United Nations Environment Programme (2007) Report of the cities and biodiversity: achieving the 2010 diversity target. Montreal: UNEP/CBD. Available at: https://www.cbd.int/doc/?meeting= MAYORS-01 Accessed 28 June 2016. 
Villegas M, Garitano-Zavala Á (2010) Bird community responses to different urban conditions in La Paz, Bolivia. Urban Ecosyst 13: 375-391

Wenny DG, Devault TL, Johnson MD, Kelly D, Șekercioḡlu CH, Tomback DF, Whelan CJ (2011) The need to quantify ecosystem services provided by birds. Auk 128:1-14
Whelan CJ, Şekercioğlu ÇH, Wenny DG (2015) Why birds matter: from economic ornithology to ecosystem services. J Ornithol $156: 227-238$

Wilman H, Belmaker J, Simpson J, De La Rosa C, Rivadeneira MM, Jetz W (2014) EltonTraits 1.0: species-level foraging attributes of the world' s birds and mammals. Ecology 95:2027 